\section{APPOINTMENTS VACANT}

APPLICATIONS are invited for the following appointments on or efore the dates mentioned :

March 27)

ASSISTANT MaNager (DEVElopMent) (Ref. No. F.176/48), Shop MANAGERS (DEVELOPMENT) (Ref. No. F.177/48), a SHOP MANAGER (Chemist) (Ref. No. F.178/48), and a Shop Manager (Plant Main TENANCE) (Ref. No. C.131/48), in the Department of A tomic Energy Springflelds Factory, Salwick, Preston-The Ministry of Labour and House, Kingsway, London, W.C.2, quoting relevant Ref. No. (March $30)$.

Statistician (No. A92/48A), and a Statistical OfFickr (No. A461/47A), in the Air Ministry-The Ministry of Labour and National Service, Technical and Scientific Register, Room 669, York House, Kingsway, London, W.C.2, quoting relevant 1 ef. No. (March 31), Kingsway, London, W.C.2, quoting revant k ef. No. (March 31 . ASSISTANT DIRECTOR (PHYSICS) -The Director,
Board, 1 Grosvenor Place, London, S.W.1 (March 31).

SENIOR EXPERIMENTAL OFFICER in the Ministry of Supply, London, to supervise the valve interests of the Signals and Radar Research to supervise the valve interests of the Signals and Radar Research Technical Valve Committees-The Ministry of I Thour and National Technical Valve Committees-The Ministry of Labour and National Kingsway, London, W.C.2, quoting D78/48A (April 3).

Kingsway, London, W.C.2, quoting D78/48A (April 3). Division of Industrial Chemistry, Melbourne-The Secretary, AusDivision of Industrial Chemistry, Melbourne-The Secretary, Australian Scientiflc Research Liaison Office, Aust

London, W.C.2, quoting No. 1623 (April 10). SECTION, Melbourne-The Secretary, Australian Scientific Research LECTION, Melbourne-The Secretary, Australian Scientific Research Liaison Office, Aust

ASSISTANT LECTURER (Grade III) IN GEOLOGY-The Registrar, Queen Mary College, Mile End Road, London, E.1 (April 15).

CHAIR OF GEOPHYSICS in the University of Istanbul-The Director, Personnel Department, British Council, 3 Hanover Street, London, W.1 (April 15)

CHAIR OF ANGLo-SAXON ARChæOLOGY at University College-The Academic Registrar, University of London, Senate House, London, W.C.1 (April 16).

Statistician in the Department of Preventive Medicine-The Secretary and Registrar, The University, Bristol (April 17)

ASSISTANT LECTURER IN BOTANY (if possible with interest or experience in cytology and genetics), an ASSISTANT LECTURER IN ORGANIC CHEMISTRY, a LECTURER IN MATHEMATICS (with special qualifications in pure mathematics), ASSISTANT LECTURERS (2, one in Applied Mathematics and one in Pure Mathematics), an Assistan' LECTURER IN PHYSICS (preferably with experience in.radar or geophysics), and an ASSISTANT LECTURER IN ZOOLOGY (preferably with experience in experimental cytology or genetics)-The Registrar, University College, Hull (April 17).

AgRICULTURAL ECONOMISTS (2), ASSISTANT AgRICULTURAL ECONOMISTS (3, Grade B), a LECTURER IN THEORETICAL PHYSICS, and an Assistant LeCtURER in Theoretical PHysics-The Registrar, The University, Manchester 13 (April 17).

ENTOMOLOGIST in the Inter-Territorial Tsetse Reclamation Department, East Africa High Commission (Kenya)-The Under-Secretary of State Colonial Office (Research Department), Palace Chambers, Bridge Street, London, S.W.1 (April 24).

LECTURERS (2) IN MECHANICAL ENGINEERING, and a LECTURER IN ELECTRICAL ENGINEERING-The Registrar, The University, Leeds 2 (April 24).

BRITSH COKE RESEARCH FeLLOWSHIP tenable in the Department of Physical Chemistry-The Registrar, King's College, Newcastle-uponTyne (April 30).

TURNER Dental School RESEaroh FELLOWShIP, and the INTERNATIONAL WOOL SECRETARIAT SCHOLARSHIP-The Registrar, The University, Manchester 13 (April 30).

PROFESSOR OF BACTERIOLOGY in the University of QueenslandThe Agent-General for Queensland, 409 Strand, London, W.C.2, or the Secretary, Universities Bureau of the British Empire, 8 Park Street, London, W.1 (Brisbane, May 31).

LABORATORY TECHNICIAN (Grade B.1, histological technique essential) IN PATHOLOGY DEPARTMENT-The Secretary, Welsh National School of Medicine, 10 The Parade, Cardiff.

AGRICULTURAL ECONOMIST, an ASSISTANT AGRICULTURAL ECON OMIST, and a DEMONSTRATOR IN PHARMACY - The Registrar, University College, Nottingham.

TECHNICAL ASSISTANT to assist in steelworks investigations, mainls in connexion with ingots and moulds-The Personnel Officer, British Iron and Steel Research Association, 11 Park Lane, London, W.1, quoting 'Ingots'.

SENIOR - LABORATORY STEWARD-The Secretary, Northampton Polytechnic, St. John Street, London, E.C.1.

ASSISTANT BACTERIOLOGIST IN VACCINE LYMPH DEPARTMENT-The Bacteriologist-in-Charge, Lister Institute, Elstree, Herts.

\section{REPORTS and other PUBLICATIONS (not included in the monthly Books Supplement)}

\section{Great Britain and Ireland}

Memoirs of the Cotton Research Station, Trinidad. Series B, Physiology, No. 18: Studies on Foliage Hydration in the Cotton Plant, vii. The Size Factor. By T. G. Mason. Pp. 143-152. (London : Empire Cotton Growing Corporation, 1947.) 28. 6d.

Economic Proceedings of the Royal Dublin Society. Vol. 3, No. 20: Chick Mortality caused by War-Grade Wheat Offals. By Brendan J. Senior and Prof. W. Kearney. Pp. 293-310. (Dublin : Hodges, Figgis
and Co., Itd. ; London: Williams and Norgate, Ltd., 1947.) 28. [225
Scientifle Proceedings of the Royal Dublin Society. Vol. 24 (N.S.) No. 18 : On a Recent Addition to the Collection of Irish Meteorites in the National Museum, Dublin. By Prof. H. J. Seymour. Pp.

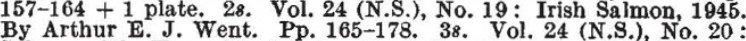
Salmon of the Kerry Blackwater. By Arthur E. J. Went. Pp. 179-188. 28, Vol. 24 (N.S.), No. 21 : Effect of Mild Strains of Virus X on the Yield of Up-to-date Potato. By Phyllis E. M. Clinch and Robert McKay. Pp. 189-198. 28. (Dublin: Hodges, Figgis and Co., Ltd. ; London: Williams and Norgate, Ltd., 1947.)
Foreign Office. Report of the Interdepartmental Commission of Enquiry on Oriental, Slavonic, East European and African Studies. Pp. 192. (London: H.M. Stationery Office, 1947.) 38. net. [225 Report of the Ministry of Health for the Year ended 31st March 1946, including the Report of the Chief Medical Officer on the State of the Public Health for the Year ended 31st December 1945. (Cmd. 7119.) Pp. vi + 194. (London: H.M. Stationery Office, 1947.) 38. $6 \bar{d}$. net. Bacteriology of Spray-dried Egg, with particular reference to Food Poisoning. By Various Authors. Pp. 66. (London : H.M. Stationery Office, 1947.) 18. net.

University of Cambridge: School of Agriculture. Memoir No. 18 A Summary of the Papers published by the Members of the Staff of the School of Agriculture and its Associated Research Institutes during the Period Oct. 1st, 1945-Sept. 30th, 1946. Pp. 28. (Cambridge : School of Agriculture. 1947.) 28. [275 Education (Scotland) Report for the Year 1946 by the Director of the Royal Scottish Museum, Edinburgh. Pp. 16. (Edinburgh: Royal Scottish Museum, 1947.)
[275 (London: A. Wander, Ltd., 1947.) Annual Report (1946). Pp. 8. Liverpool Observatory and Tidal Institute. Annual Report, 1946. Pp. $14+3$ plates. (Liverpool : Liverpool Observatory, 1947.) [275 Soll Sterilization, with Special Reference to Glasshouse Crops. Fourth edition. Pp. iv $+22+10$ plates. $1 s .3$ d. net. Bulletin No. 95: Strawberries. Third edition. Pp. iv +38.28 . net. (London: H.M. Stationery Office, 1947.)

\section{Other Countries} Indian Forest Bulletin. No. 130 : The Effects of Burning on the
Soil as a Preliminary to Artiflcial Regeneration. By Dr. A. L. Griffth. Pp. iv + 34. 1.4 rupees ; 28. No. 132: The Price-Age Gradient of Bori (Hoshangabad, C.P.) Teak. By Bakhshi Sant Ram. Pp. $v+15+8$ Bori (Hoshangabad, C.P.) Teak. By Bakhshi Sant Ram. Pp. $\mathbf{v}+15+8$
plates. 1.4 rupees; 28. (Dehra Dun: Forest Research Institute, plates. 1.4 rupees; 28. (Dehra Dun : Forest Research Institute,
[225] Fieldiana: Zoology. Vol. 31, No. 11: A New Race of Koklas Pheasant. By Robert $\mathrm{L}$. Fleming. Pp. 93-96. 10 cents. No. 12: Some Neuropterous Insects from Szechwan, China. By Nathan Banks. Colombia. By Karl P. Schmidt. A New Kinosternid Turtle from The Malleus (Ossiculum auditus) of the 109-112. 10 cents. No. 14 : Segall. Pp. 113-120. 10 cents. No. 15: Notes on Philippine Mosquitoes, ii, A New Species of Tripteroides. By F. E. Baisas. Pp. 121-124. toes, ii, A New Species of Tripteroides. By F. E. Baisas. Pp. 121-124. 10 cents. (Chicago: Chicago Natural History Museum, 1947.) [225 Fieldiana: Zoology. Vol. 32, No. 1 : Phalangida from Tropical
America. By Clarence J. and Marie L. Goodnight. Pp. 58. 75 cents. America. By Clarence J. and Marie I. Goodnight. Pp. 58. 75 cents.
(Chicago: Chicago Natural History Museum, 1947.) Smithsonian Miscellaneous Collections. Vol. 107, No. 1: The Ethnogeographic Board. By Wendell Clark Bennett. (Publication 3889.) Pp. viii + 135. (Washington, D.C.: Smithsonian Institution, 1947.)

Report of the Science Service, Dominion Department of Agriculture, for the Year ended March 31, 1946. Pp. ii +88. (Ottawa: King's Printer, 1946.)

Excerpta Medica: Fifteen Journals containing Abstracts of the World's Literature in the Field of Clinical and Theoretical Medicine. Section 1 : Anatomy, Anthropology, Embryology and Histology. 22 dollars; $£ 5.12 .0$ a year. Section 2: Physiology, Biochemistry and Pharmacology. 45 dollars ; $\mathfrak{f 1 1 . 3 . 0}$ a year. Section $3:$ Eudocrinology. 15 dollars ; 3.15 .0 a year. Section $4:$ Public Health and Social and Industrial Medicine. 22 dollars ; $£ 5.12 .0$ a year. Section 5 : General Patbology, Pathological Anatomy and Bacteriology. 37.50 dollars ; $£ 9.6 .0$ a year. Section 6 : Internal Medicine. 37.50 dollars; $£ 9.6 .0$ a year. Section 7 : Pediatrics. 15 dollars; $£ 3.15 .0$ a year. Section 8 : Neurology and Psychiatry. 22 dollars; $\$ 5.12 .0$ a year. Section 9 Surgery. 25 dollars; $£ 6.4 .0$ a year. Section 10 : Obstetrics and Gynaecology. 15 dollars; $£ 3.15 .0$ a year. Section $11:$ Oto-, Rhino-, Laryngology. 15 dollars; $£ 3.15 .0$ a year. Section $12:$ Ophthalmology. 15 dollars; $£ 3.15 .0$ a year. Section 13 : Dermatology and Venereology. 25 dollars; $£ 6.4 .0$ a year. Section 14 : Radiology. 15 dollars ; $£ 3.15 .0$ a year. Section 15: Tuberculosis. 15) dollars ; £3.15.0 a year. (Amster-
dam: N.V. Excerpta Medica, 1947).
Dermatology and Venereology : Being Section 13 of Excerpta Medica. Vol. 1, No. 1, April. Pp. 96. (Amsterdam: N.V. Excerpta

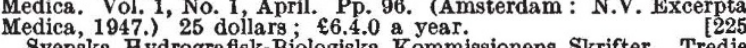
Svenska Hydrografisk-Biologiska Kommissionens Skrifter. Tredje Serien, Hydrograf, Band 1, Häfte 2 : The Piston Core Sampler. By
B. Kullenberg. Pp. 46. (Göteborg : Elanders Boktryckeri A.-B., B. Kullenberg. Pp. 46. (Goteborg: Elanders Boktryckeri A,-B.,
[275 Tekniska Föreningen I Finland: Medlemsförteckning. Pp. $\mathrm{vi}+56$ + xxiv. (Helsingfors: Mercators Tryckeri, 1947.) [275 Rubber Research Institute of Malaya. Planting Manual No. 4:
Latex Preservation, Concentration and Shipment. By J. H. Pidford. Latex Preservation, Concentration and Shipment. By J. H. Pidford. Second edition. Pp. iii +76 . (Kuala Lumpur: Rubber Research
Institute of Malaya, 1947.) 2 dollars.
[275 Institute of Malaya, 1947.) 2 dollars.
Union of South Africa : Department of the Interior. Report of the Archaeological Survey of the Union of South Africa for the Period 1st April 1940 to 31 st March 1946; being a Summary of Annual Reports Nos. 6, 7, 8, 9, 10 and 11. Pp. 15. (Pretoria : Government

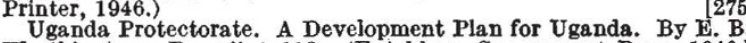
Worthington. Pp. xii +112 . (Entebbe: Government Press, 1946.)
28. 6d. 